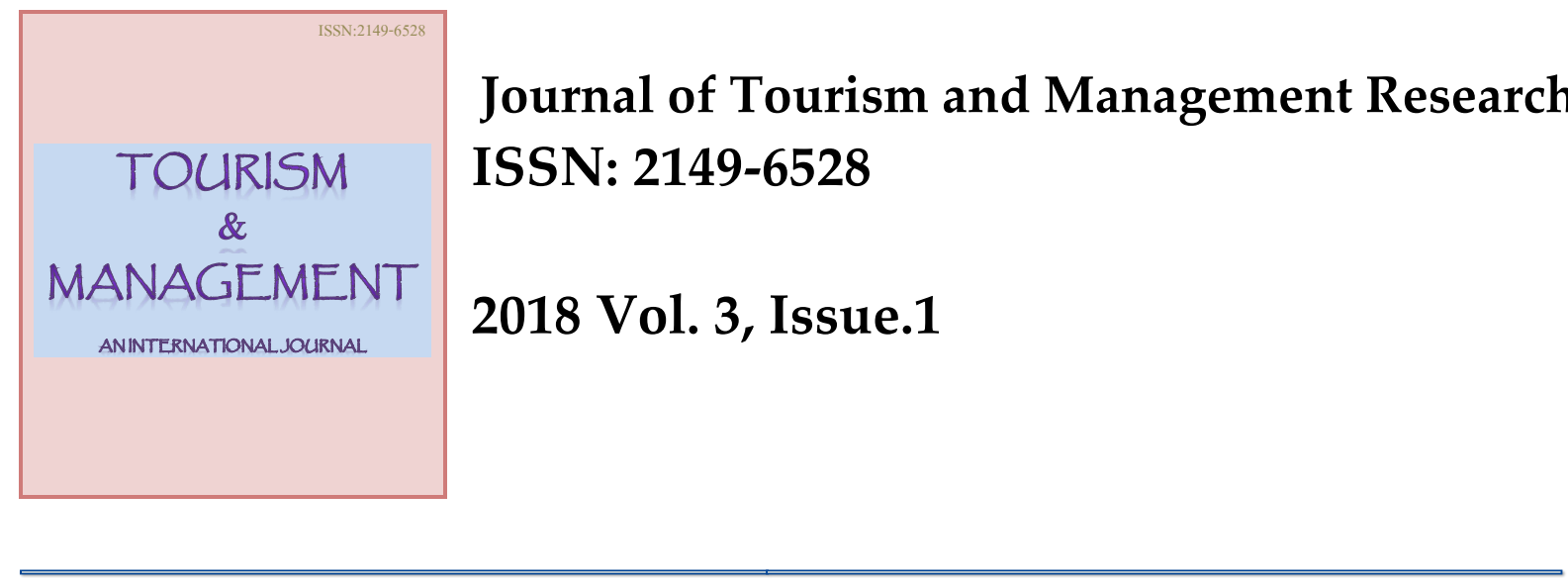

\title{
Tourism Endorsement in Sacred Jammu and Kashmir: A Research on Peace and Tranquillity
}

\begin{abstract}
The current research aims to examine the importance of tourism development as an essential element for building peace in Kashmir and Jammu (J\&K). Peace through tourism is the reduction and eventual elimination of the conditions that lead to the violence. This research has also aimed to look after religious tourism, which has great potential for rejuvenating the dormant religious beliefs of people and the cross-border trade that will open new routes for harmony by securing each other's interests. Non-probability convenience random sampling technique was used to select the sample. Self-administered questionnaires were distributed amongst 275 local residents in $\mathrm{J} \& \mathrm{~K}$, where 240 questionnaires were received back and found to be useful. Data was analysed by using SPSS version 21.0. The findings of current research confirm that the stakeholders and community play a major role in shaping the development and promotion of sustainable destination. Tourism contributes positively to the guest-host relationship, regional economy to increase in income and cross-cultural understanding. Further, findings of current research also disclose that tourism plays an essential role for promoting peace, which leads to cross-cultural interaction resulting intolerance, national integration, compassion, goodwill, educational standards, justice and mutual respect for each other. Implications, limitations of the study and future research suggestions are also discussed.
\end{abstract}

Keywords: Peace, Tourism, Stakeholders, Destination promotion, Religious, Tranquillity, Jammu and Kashmir

Jel Classifications: Z32; Z12; R58

Parikshat Singh Manhas, School of Hospitality and Tourism Management, University of Jammu, Baba Saheb Ambedkar Road, Jammu Tawi (J\&K)-180006, India.

Email: psmanhas@hotmail.com / Tel: +919419188260.

Kashif Hussain, Prof.Dr. Faculty of Hospitality and Tourism Management, UCSI University Kuala Lumpur Campus No. 1, Jalan Menara Gading, UCSI Heights (Taman Connaught), Cheras 56000 Kuala Lumpur, Malaysia.

Email: kashif@ucsiuniversity.edu.my / Tel: +60 102001784. 
Jeetesh Kumar, Assist.Prof.Dr. (Corresponding Author) Faculty of Hospitality, Food and Leisure Management, Taylor's University, No. 1 Jalan Taylor's, 47500 Subang Jaya, Selangor Darul Ehsan, Malaysia.

Email: himsian@hotmail.com / Tel:_+60 102535574.

Priyanka Sharma, School of Hospitality and Tourism Management, University of Jammu, Baba Saheb Ambedkar Road, Jammu Tawi (J\&K)-180006, India.

Email: priyanka.sharma@hotmail.com

\section{Introduction}

Tourism has always been a peace-based industry and is a facilitator of global peace. Tourism builds cross-cultural relations and is a vital force for positive peace. Tourism is a most effective mechanism for fostering national and global cultural exchange and understanding among people. Tourism is now 'the largest service industry in the world on virtually any economic appraise,' and is progressively on growth pathway. International tourism receipt represents $7 \%$ of worldwide exports. In terms of tourist's receipt destinations reached US\$ 1260 billion (euro 1136 billion) in 2015. In real terms, i.e. taking into account exchange rate fluctuations and inflation, this represents an increase of $4.4 \%$ over 2014, mirroring the growth in international arrivals. International tourist arrival has improved from 25 million in 1950 to 1186 million in 2015, and according to the World Tourism Organization's vision forecasts, it will continue to grow by about $3.3 \%$ per year to reach 1.4 billion by the year 2020 and 1.8 billion by the year 2030 (UNWTO, 2016). As the scale of tourism is huge, its impact should also be great. Thus, an effective nation-builder and a strong motivation and cause for peace.

In a competitive era, tourism is an approach for promoting peace and communal understanding. It is consider as a force to encourage social justice and resolution within a divided society (Higgins-Desbiolles, 2003). Peace cannot be definite as an exact situation. 'Peace is a vital prerequisite for travel and tourism and all aspects of human growth and development'.

The state of Jammu and Kashmir (J\&K) formed on $26^{\text {th }}$ of October 1947 is the sixth largest state in the area. The tourism industry is the most flourishing industry and plays an important role in the development of the state. It is a major economic activity in the state. Kashmir has also known as paradise on earth has rich geographical diversity. The Valley has enormous tourist potential due to its scenic beauty, climatic conditions, culture, ambrosial cuisine and adventurous sports. Travel to Kashmir during spring is a great experience as the mountains covered with snow. However, the tourism industry in Kashmir has suffered a lot due to violence. It has declined since 1980, with the emergence of terrorism (Ranga \& Pradhan, 2014). It became a risky place for the tourists to visit.

Tourism cannot survive in war and conflict. Conflict and instability are the two main reasons for the underdevelopment of the major tourists' destinations in the valley. There is a strong relationship between conflict and development and it is a two-way process: conflict retards development and failure in development increase proneness to conflict (Rukuni et al. 2015). The present study emphasises avoiding these conditions through channels of tourism. Conflict in Kashmir had started since the partition of India in 1947. India and Pakistan had developed bitter enmity over Kashmir. The two countries have war twice over Kashmir (1947, 1965 \& 1971), and the Kargil conflict of 1999. India and Pakistan are caught in a classic 'prisoner's dilemma' situation over Kashmir (Rid, 2015). India's denial to execute United Nations Security Council's (UNSC) resolutions calling for a plebiscite in Kashmir as a peaceful means of settling the dispute between the two neighbours has prevented its settlement to this date. Due to insurgency and militancy, tourist arrival decreased, some 
tourist spots either shrunk or completely disappeared. Violent protest, terrorist attacks, social unrest, bombings in the state had caused tourists to alter their destination. Violence has an inverse impact on the number of tourist arrivals. Violence in the state had also affected the handicraft industry, horticulture, and agriculture.

The tourism could further bring the desired level of closeness among the people and may go a long way in creating a peaceful environment. In other words, tourism for peace (TFP) brings hosts and guests together in a particular country. Those visiting it, mutually learn about peace by understanding and realising varied cultural beliefs, art, music, foods, stories, spiritual ceremonies, and by linking with the natural world. Further, responsible tourism is also a principle of sustainable tourism as well as world peace (Leong, 2008). Besides this, tourism is making a contribution to peace when it contributes towards the (works) abolishment of war, elimination of violence, awareness, and action for expansion of global and environmental issues (Upadhayaya, 2013). Tourists are also sensitive to wars because violence in their holiday destination can be a threat to their lives and can deprive them of relaxed and carefree holidays (Cole \& Neumayer, 2004). They avoid visiting any place with violence and might choose an alternative destination with stable conditions. Tourism has lots of advantage for the local community, if every member performs their role actively, tourism must lead to peace. Every traveller must keep in mind that every place has their own way of life, values, and beliefs, which they should respect, and this would develop a harmonious relationship among the hosts and the travellers and its impact on the peace-building process.

The growth of tourism industry can have a significant impact on the overall growth of a region, reason being, its capability to generate employment and trade. Tourists are conflict sensitive and respond positively to peace. Peace and sustainability, measured as the indicator of expansion are vulnerable due to a numerous of conflicts including social, economic, political, cultural and environmental. Tourism, which holds the key to the promotion of peace and sustainability. This paper examines the importance of sustainable development as an essential element for building peace to promote tourism and community participation in it. Peace through tourism is the reduction and eventual elimination of the conditions that lead to the violence.

In addition to, tourism can be a catalyst to promote track one diplomacy and to develop or maintain negative peace, at the same time it emphasises the importance of challenging the efforts in tourism towards positive peace. As tourism is a major player in spreading peace, as it operates at the most basic level by spreading information about the personalities, beliefs, aspirations, perspective, culture and politics of one country to the citizens of another. Besides this, stakeholders play an integral part in the formulation of tourist friendly destination concept inculcating tourists, industries, and hosts. These stakeholders work together in the formulation and composition of tourist friendly destination concept through a combination of 3 As including 'Attraction, Accessibility and Accommodation' (Robinson, 2012). WTO outlines the tourism industry's role to generate new openings for business, employment, income and foreign exchange through the prerequisite of tourism services including transportation, accommodation, food and beverages. In the meantime, the 'environment's role is to create an attention of tourists to participate in activities based on local culture, nature, architecture (man-made). Finally, the local resident and local businesses, organisations, and associations function to make decisions (Haywood, 1988). The state of $\mathrm{J} \& \mathrm{~K}$ is full of divine sites and most of these are located in between the scenic surroundings of great Himalayas. This phase is prone to attracting a huge number of Tourist every year, which has eventually led to a boom in the tourism Industry of the state. In this state symbolises religious equality and welcomes people from all religions. This state stands as an essence of a religious tolerance.

The current study focuses on religious tourism, which has great potential for rejuvenating the dormant religious beliefs of people and the cross-border trade that will open new routes 
for harmony by securing each other's interests. To accomplish the aim of the study, three objectives have been set out:

- To explore the significance of tourism in peace initiatives;

- To study the stakeholders' perception and participation across borders destinations for peace initiatives;

- To explore the relationship between religious tourism and cross-border tourism.

\section{Literature Review}

\subsection{Tourism as a Catalyst for Peace and Development}

The relationship between peace and tourism is very interesting because both are complementary to each other. Tourism can be an essential force for peace and alternatively, tourism needs peace for its expansion and prosperity. Tourists are generally sensitive to the event of war, violent behaviour because 'such events risk a peaceful and undisturbed holiday'. They avoid visiting places with a negative reflection and simply switch to another destination when they find there is no serenity in their destination. Several countries throughout the world, where heinous violent incidents have resulted in negative impact on the tourist's inflow to those countries. Nowadays war, terrorism and state violence have affected tourism largely and countries highly dependent on tourism for national economic growth affected due to decline number of visitors. Tourism is a vital industry, which requires peace and silence in order to stay alive and flourish.

Tourism as a social force promotes international understanding, cooperation, and global goodwill in establishing and keeping world peace (D'Amore, 1988). Tourism can give tourists first-hand experiences with hosts of different cultures and subsequently become aware of their personalities, beliefs, aspirations, and culture and life perspectives. Tourism searches for peace, stability, and harmony for its development and prosperity (Mihalic, 1996; Tarlow, 2006). Being a powerful socio-economic force and responsive to peace tourism can play a potential role of supporter to mitigate conflict and support post-conflict peacebuilding. (Edgell, 1990) suggested the demand for peace for tourism, even marking as 'peace: passport to tourism', support the argument for peace through tourism.

The role of sustainable and participatory tourism is important for the casual relationships of tourism for peacebuilding. In order to build sustainable tourist destination, an organised management is necessary. Sustainable development in tourism depends on the participation of all stakeholders within a tourism industry or a destination. The purpose of the stakeholder concept in sustainable development is to identify potential interest and influential groups in tourism to involve the interested and influential groups in tourism and enable their participation in order to give socioeconomic affluence to everyone (Gunsoy \& Hannam, 2013). Tourism development yields objective impacts on the host population and destination. As an economic development tool, tourism can improve the local community's quality of life via employment, investments, tax revenues, restaurants, accommodation services, natural attractions, culture, and festivals (Etiosa, 2012). Tourism expansion in border areas generally connects with political and economic worldwide changes during the 20th century. These changes include development in international trade and cash flow, promotion, monetary individual and universal corporations (Anderson et al., 2002; Butler, 2002; Hall, 2005; Ioannides et al., 2006; Sofield, 2006).

The relationship between border and tourism states that the conservative border functions have been shifted, both conceptually and physically (Timothy, 2001). Border tourism reflects connectivity for a better understanding and expansion of tourism in dynamic areas. Usually, borders and border areas have been barriers to tourism both accurate and perceptual aspects related to conflicts, administrative and psychological obstacles (Hall, 2005; Sofield, 2006; Timothy, 2001). Border areas include social, monetary and safety interrelations happening in them and not by range or size (Hageman, et al., 2004; Kristoff, 1959; Newman, 2011; 
Prescott, 1965; Sofield, 2006). Tourist sites located in border areas comprises of theme-based attractions such as cross-border parks, natural attractions, heritage tourism and religious tourism (Timothy, 2001). Religions are distinct from one another at the level of rituals and myths but they share some common ethics, values, and desires of the human mind and society. Ultimately, all religions are determined to spread love, peace, happiness. The best manner to get harmony among the world's religions is the development of tourism. Tourism serves as a vehicle for removing conflict by facilitating peace and unity (Raina \& Aggarwal, 2004). 200 million tourist travels all over the globe every year which gives them great opportunities to meet different religions of the world and hence it promotes inter-religious understanding and harmony.

Tourism establishes religious harmony by bringing people of different religious into close contacts (Van Sterkenburg, 2012). The border does propose a great prospect to present stability and safety in the region and improve the travelling experience of visitors to each country (Timothy, 2001).

\subsection{Tourism and Peace Initiatives}

Tourism as an approach promotes peace by solving the problems of poverty, unemployment, etc. Tourism plays an essential role in promoting world peace (Salazar, 2012). Further, tourism interventions are sets of expressions, language, and behaviours that depict places and peoples and turn sites into easily consumable attractions. In other words, tourism is a social creation, which deals with the many desires of people of the modern industrialised world. Besides this, tourism is a ground in which many individuals interact and discuss with one another which creates a sense of unity (Chettiparamb \& Kokkranikal, 2012). The involvement of individual of J\&K in the peace process gained thrust in the year 2005 and 2006. However, the initiatives of bus service between Srinagar and Muzaffarabad termed as the mother of all assurance building measures. The year 2005 observed the stays of many delegations from both sides across the LOC. The people-to-people communications have given a marvellous boost to hopefulness regarding the conclusion of the ongoing peace process. It provides a prospect for people from both sides of LOC to know each other and to see the realities on the ground on the other side. These links revived old sentiments of belongingness and fraternity among the people from both sides. Further, these talks provided an opportunity to the members of civil society to think separately of their respective governments. Besides this, People-to-People contacts such as the 'heart-to-heart' talks in Jammu and New Delhi in 2005 and 2007 provided the chance for the leaders and activists of different shades from both sides of LOC to speak their heart on a single platform.

Tourism and peace are two interrelated terms. Tourism is a catalytic force for unease reduction and peacebuilding ( $\mathrm{Yu} \&$ Chung, 2001). 'Tourism and Peace: The State of the Art' - it would be very naive to believe that these contacts automatically lead to a decline of injustices, a new, more tolerant worldview and a better understanding of each other. The peace through tourism scheme stands on the belief that cultural perceptions can promote attitude change and hence facilitate peace (Jimenez \& Kloeze, 2014). Peacebuilding can generate social harmony and equal participation in development mainstreaming creating the foundation for lasting peace (Lai et al, 2015). Tourism is beneficiary for both negative and positive peace. Positive peace is the absence or reduction of violence of all kinds, whereas negative peace leads to violence and conflict (Upadhayaya, 2013).

\subsection{Stakeholders' Involvement across Borders for Peace Initiatives}

Stakeholder referred to any group or individual who can affect or affected by the achievement of the organisation's objectives (Donaldson \& Preston, 1995). Providing peace, safety and justice necessitate the contribution of all stakeholders. Stakeholder's contribution to developing into a formation of tourist destination notion including tourists (as the demand), 
industries (Private sector, the non-profit sector and public sector as the supply) and hosts (comprising the neighbouring commune and natural surrounds as the recipients of the effects). The tour operator is an intermediary between the supply and demand sides through which customer's preferences reach the producers, and services reach the destination (Budeanu, 2005). However, tourism destination development is important to make possible enhancing or improving the sustainability significance of a tourism destination by stakeholder's participation. Tourism in Cross-Border Regions (CBR) consists of short trips from one side of the boundary to the other that enables them to transfer information between neighbouring border regions using related tourism resources (landscape, culture, history) and exchange comparable tourism products. Cross-border tourists from adjoining countries and regions share a geographic and cultural relationship with the destination communities, which enhance their potential contribution to providing more viable ideas for innovations. Tourism is inclined by supporting limitations and by border-related administration policies, managerial operations on both sides of the border and the physical and psychological barriers produced by the borders against human mobility and associations, including the movement of people, goods, and services between countries (Prokkola, 2010).

In other words, Stakeholders exposed the interrelationship between peace and development, the importance of good governance for peace and development and the need to integrate and strengthen community and national level peacebuilding efforts. According to WTO, a stakeholder in sustainable tourism development is divided into three categories (Timur, 2012) as shown in Table 1.

Table 1: Stakeholder's categories.

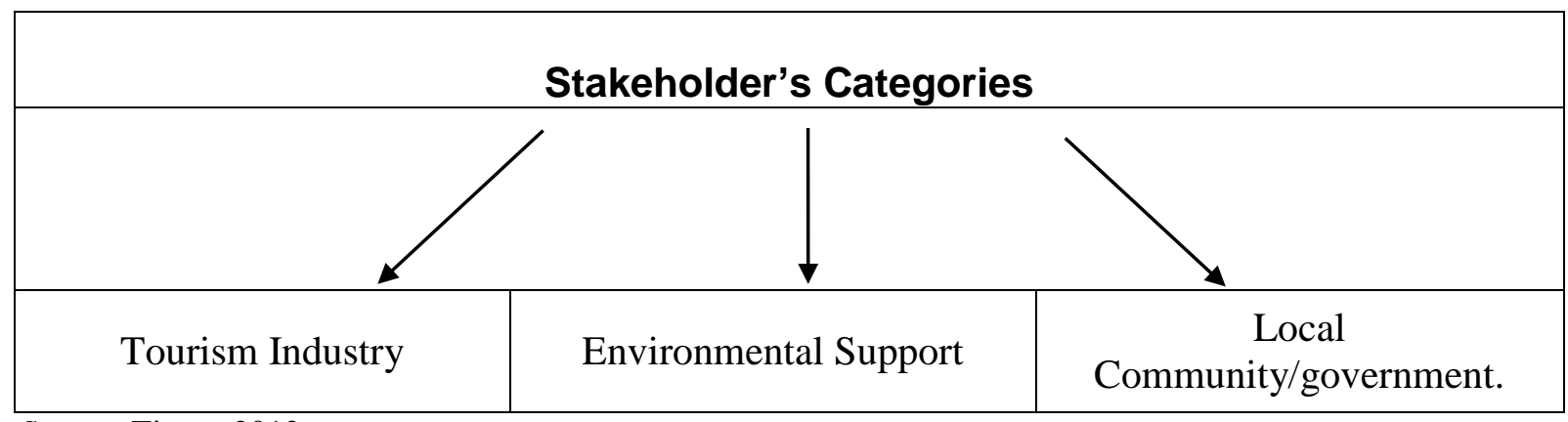

Source: Timur, 2012.

\subsection{Stakeholder's Perception of Tourist as a Peace Initiative}

Stakeholder groups persuade the development of tourism in numerous ways as well as tourism supply and demand, regulation, and the management of tourism impacts, human resources and research (Waligo, 2012). Perceptions of various stakeholders toward the development of tourism in a society should be taken as the first place in tourism planning in order to make certain trust, cooperation, harmony and mutual benefit for all (Kuvan \& Akan, 2012).

In the wider term, the sustainability of the surroundings; i.e. ecology, social structure, and culture mean nothing more for the tourist industry than the preservation of the proportional advantage of the destinations, the loss of which indicates a determinant cause for a refuse in competitiveness (Gill \& Williams, 1994). Therefore, it is a vital role to recognise stakeholders managing tourism more sustainably and to take account of their different perspectives on the issues (Dodds, 2007). Stakeholders should not only be the beneficiary of sustainable tourism plans but active participants in the planning process (Ritchie \& Crouch, 2003).

\subsection{Religious Tourism across Border}


No religion preaches violence and conflict or militancy. Every religion believes in harmony and peaceful co-existence of all citizens (Farajat et al. 2017). Religion does not promote 'extremism', it preaches religious tolerance i.e. people should try to embrace cultural as well as religious diversity. They should not develop hatred towards any community or sacred groups and must not engage in communal riots but should respect beliefs and customs of different religions. Another aspect of the imitative is to teach people not to stereotype any religious group i.e. we should stop labelling of a religious group as a terrorist group. Different shrines and places across borders that are the real examples of communal and religious harmony. The aim of undertaking this initiative was to teach that the local innocent people have to suffer a lot because of the violence through communal riots and religious agitations. In 1947, two new countries were born and people, ideologies and humanity were alienated. In past years, people are fighting in the name of religion and community but nowadays all these things are abolished. For instance, Suchetgarh (a village in Sultanpur Lodhi in Kapurthala district of Punjab State, India) having Muslim as well as Hindu shrine under one roof (Anees et al, 2015). It was fascinating to know from the residents of that area that people from both religious conviction worship here and pay homage with no envy for another religious group. This is the perfect example of religious harmony and religious tolerance. Another such example is of Baba Chamliyal a place at Indo-Pak border in Samba district of J\&K, a real example of the communal and religious harmony. The Holy Dargah (shrine) of Baba Chamliyal is nearly 320 years old. A three-day fair is organised every year at this Dargah (shrine) on every fourth Friday of the month of June and popularly known as Baba Chamliyal Mela amongst the residents as well as the visitors. The uniqueness of the Holy Dargah is that people from both sides of the border take part in this fair, India's Border Security Force and Pakistan's Chenab Rangers handle the fair annually. They help the people from both sides of the border to receive the sacred items- Sharbat (holy water) and Shankar (holy soil) which is believed to have healing capacity against skin ailments. The welfare of the humankind should be given prime importance and efforts should be done to build peace and harmony at all the borders. They also emphasised that because of the violence issues people are restricted to visit the shrine, therefore, peace should be built so that they can pay homage at the shrine.

\section{Methodology}

\subsection{Sampling, Data Collection and Survey Instrument}

The tourism industry is the most flourishing industry and plays an important role in the development of the state. It is a major economic activity in the state. Kashmir has also known as paradise on earth has rich geographical diversity. The Valley has enormous tourist potential due to its scenic beauty, climatic conditions, culture, ambrosial cuisine and adventurous sports. For this reason, the $J \& K$ region has been selected as a research area. A group of four junior researchers (masters students) from the university were involved to collect the data from residents (adults) of J\&K in the month of December 2016.

For the current research, 275 survey questionnaires were distributed on the basis of a non-probability convenience sampling technique (Amick \& Walberg, 1975). Of these, 240 questionnaires were returned representing $87.3 \%$ response rate to the original sample of the study. A structured questionnaire has been used to collect and gather the data. The measurement scale of the questionnaire for all items was based on 5-Likert scale, and that scale range from ' 1 ' being 'strongly disagree' to ' 5 ' being 'strongly agree'.

The current measurement scale was based on four (4) independent variables including; Tourism - Tool for Community Development (4 items), Border Tourism (4 items), Local Community's Perception (3 items), Role of Stockholder for Peace Initiatives (3 items) and one (1) dependent variable, Peace and Tranquillity by Border and Religious Tourism (9 items). All items have been derived/adapted from several studies including; Anderson et al. (2002), Bhat (2014), Budeanu, (2005), Chettiparamb \& Kokkranikal (2012), Cole \& 
Neumayer (2004), Donaldson \& Preston (1995), Gunsoy \& Hannam (2013), Ioannides et al. (2006), Kristoff (1959), Kuvan \& Akan (2012), Lai et al. (2015) and Newman (2011).

\section{Results}

\subsection{Demographic Breakdown of the Sample}

Results show that $57.5 \%$ of the respondents were males. The majority of the respondents fall under the age group ' $31-40$ ' $(42.5 \%)$, which represents a mature range of the respondents in age. In terms of respondents' education level, the majority of them were holding only high school certificates $(40.8 \%)$ followed by degree (bachelors) $(31.7 \%$ ) and postgraduates $(15.8 \%)$.

Table 2: Demographics of the respondents.

\begin{tabular}{|l|c|c|}
\hline & Frequency & Percentage (\%) \\
\hline Gender & & \\
\hline Male & 138 & 57.5 \\
\hline Female & 102 & 42.5 \\
\hline Total & 240 & 100.0 \\
\hline Age & & \\
\hline Below 30 & 62 & 25.8 \\
\hline $31-40$ & 102 & 42.5 \\
\hline 41-50 & 33 & 13.8 \\
\hline 51 or above & 43 & 17.9 \\
\hline Total & 240 & 100.0 \\
\hline Education & & 40.8 \\
\hline High School & 98 & 11.7 \\
\hline Diploma & 28 & 31.7 \\
\hline Degree (Bachelors) & 76 & 15.8 \\
\hline Post Graduate & 38 & 100.0 \\
\hline Total & & \\
\hline
\end{tabular}

\subsection{Psychometric Properties}

Table 3 demonstrates that the overall reliability (internal consistency) of the study was found to be coefficient alpha 0.810, which is deemed acceptable (Churchill, 1979; Nunnally, 1978), which suggests that the measures were free from random error and thus reliability coefficients estimate the amount of systematic variance (Churchill, 1979, p. 4). Reliability analysis is well known as to test the 'degree of consistency between measures of the scale' (Mehrens \& Lehman, 1987), when each factor (study constructs) were examined, it was found to be reliable with coefficient alpha more than 0.60 at aggregate level, cut-off point (Churchill, 1979). The high alpha values indicated good internal consistency among the items, and the high alpha value for the overall scale indicated that convergent validity was met (Parasuraman et al. 1991).

Table 3: Reliability analysis of the study.

\section{Construct}

Cronbach Alpha

(a)
No. of

Items 


\begin{tabular}{|l|c|c|}
\hline Tourism - Tool for Community Development & 0.675 & 4 \\
\hline Border Tourism & 0.664 & 4 \\
\hline Local Community's Perception & 0.623 & 3 \\
\hline Role of Stockholder for Peace Initiatives & 0.701 & 3 \\
\hline Peace and Tranquillity by Border and Religious Tourism & 0.729 & 9 \\
\hline Overall & 0.810 & 23 \\
\hline
\end{tabular}

An exploratory factor analysis had been performed using principal components analysis with varimax rotation. Total variance explained was $64.847 \%$ with KMO value 0.671 . As shown in Table 4, all the items were properly loaded into their corresponding dimension with the factor loading of equal or greater than 0.6. which is quite acceptable (Field, 2000; Nunnally, 1978).

Table 4: Exploratory factor analysis.

\begin{tabular}{|c|c|c|c|c|c|}
\hline & \multicolumn{5}{|c|}{ Components } \\
\hline & 1 & 2 & 3 & 4 & 5 \\
\hline Item 1 & 0.762 & & & & \\
\hline Item 2 & 0.625 & & & & \\
\hline Item 3 & 0.570 & & & & \\
\hline Item 4 & 0.806 & & & & \\
\hline Item 5 & & 0.736 & & & \\
\hline Item 6 & & 0.833 & & & \\
\hline Item 7 & & 0.665 & & & \\
\hline Item 8 & & 0.615 & & & \\
\hline Item 9 & & & 0.534 & & \\
\hline Item 10 & & & 0.847 & & \\
\hline Item 11 & & & 0.682 & & \\
\hline Item 12 & & & & 0.643 & \\
\hline Item 13 & & & & 0.710 & \\
\hline Item 14 & & & & 0.743 & \\
\hline Item 15 & & & & & 0.673 \\
\hline Item 16 & & & & & 0.814 \\
\hline Item 17 & & & & & 0.784 \\
\hline Item 18 & & & & & 0.789 \\
\hline Item 19 & & & & & 0.840 \\
\hline Item 20 & & & & & 0.820 \\
\hline Item 21 & & & & & 0.833 \\
\hline Item 22 & & & & & 0.640 \\
\hline Item 23 & & & & & 0.659 \\
\hline
\end{tabular}

\subsection{Mean Scores}

The mean and standard deviation of different items are shown in Table 5. Literature supports that religious tourism helps to promote the cross-cultural exchange in J\&K region. Respondents were asked to ascertain their opinion regarding the contribution of religious tourism helping the promotion of destination in $\mathrm{J} \& \mathrm{~K}$ in terms of various variables. The respondents hold the opinion that religious tourism helps to promote the destination in $\mathrm{J} \& \mathrm{~K}$ attains maximum mean 4.96 and the border tourism will help to promote destination among 
the nations with maximum mean 4.92 and it is followed by Tourism helps to build mutual understanding among people. Which indicates that the religious tourism influences the promotion of destination in $\mathrm{J} \& \mathrm{~K}$.

Table 5: Mean and standard deviation.

\begin{tabular}{|c|c|c|c|}
\hline No. & Items & Mean & $\begin{array}{l}\text { Standard } \\
\text { Deviation }\end{array}$ \\
\hline 1 & $\begin{array}{l}\text { Tourism brings a positive contribution to economic growth of } \\
\text { our community. }\end{array}$ & 4.34 & 0.63 \\
\hline 2 & $\begin{array}{l}\text { Tourism becomes a platform for skill training and learning } \\
\text { new ideas for the community development. }\end{array}$ & 4.10 & 0.91 \\
\hline 3 & Tourism promotes cultural restoration and conservation & 4.06 & 0.84 \\
\hline 4 & $\begin{array}{l}\text { Tourism promotes pride of the way of life and cultures } \\
\text { among community members. }\end{array}$ & 4.72 & 0.87 \\
\hline 5 & Tourism across the border will help to raise the quality of life. & 4.22 & 0.75 \\
\hline 6 & $\begin{array}{l}\text { Border tourism will increase the employment opportunities } \\
\text { for youth. }\end{array}$ & 3.90 & 1.08 \\
\hline 7 & $\begin{array}{l}\text { Border tourism will help to fulfil infrastructure requirements } \\
\text { of the destination. }\end{array}$ & 4.04 & 0.98 \\
\hline 8 & Border tourism promotes trade relations among nations. & 4.80 & 0.96 \\
\hline 9 & $\begin{array}{l}\text { I believe that because of tourism the environment in my } \\
\text { community is well preserved. }\end{array}$ & 4.16 & 0.89 \\
\hline 10 & $\begin{array}{l}\text { I believe that tourism helps to build mutual understanding } \\
\text { among people. }\end{array}$ & 4.87 & 0.85 \\
\hline 11 & $\begin{array}{l}\text { I believe that border tourism will help to promote cross- } \\
\text { culture among the nations. }\end{array}$ & 4.92 & 0.62 \\
\hline 12 & $\begin{array}{l}\text { Good personal relations (contacts) of stakeholders and cross- } \\
\text { border individuals act as a major element in creating peace. }\end{array}$ & 4.34 & 0.88 \\
\hline 13 & $\begin{array}{l}\text { Linguistic skills of tourism stakeholders at a particular } \\
\text { destination in cross-border areas help in sustaining peace. }\end{array}$ & 4.71 & 0.85 \\
\hline 14 & $\begin{array}{l}\text { Participation of stakeholders in tourism activities across the } \\
\text { border will be very helpful for the J\&K region. }\end{array}$ & 4.59 & 1.09 \\
\hline 15 & $\begin{array}{l}\text { Border tourism will promote peace process among the } \\
\text { nations. }\end{array}$ & 4.67 & 1.03 \\
\hline 16 & Border tourism is safe to be promoted in India. & 4.23 & 1.08 \\
\hline 17 & $\begin{array}{l}\text { Promotion of border tourism will broaden the perspective of } \\
\text { political relations. }\end{array}$ & 3.62 & 0.85 \\
\hline 18 & $\begin{array}{l}\text { Border Tourism will help in the cross-cultural promotion of } \\
\text { the economy. }\end{array}$ & 3.57 & 1.02 \\
\hline 19 & $\begin{array}{l}\text { Border tourism will bring peace and tranquillity to } \mathrm{J} \& \mathrm{~K} \\
\text { region. }\end{array}$ & 4.34 & 1.12 \\
\hline 20 & $\begin{array}{l}\text { Border Tourism will not hamper the sustenance of } \\
\text { destination. }\end{array}$ & 4.44 & 0.78 \\
\hline 21 & $\begin{array}{l}\text { Religious tourism across the border will bring peacebuilding } \\
\text { process. }\end{array}$ & 4.67 & 0.75 \\
\hline 22 & $\begin{array}{l}\text { Religious Tourism helps to promote the cross-culture } \\
\text { exchange. }\end{array}$ & 4.96 & 0.89 \\
\hline 23 & $\begin{array}{l}\text { Tourism development in } \mathrm{J} \& \mathrm{~K} \text { will bring more advantages } \\
\text { than disadvantages. }\end{array}$ & 4.81 & 0.9 \\
\hline
\end{tabular}




\section{Conclusion, Implications and Limitations}

As supported by previous studies including (D'Amore, 1988; Newman, 2011), this research confirms that the stakeholders and community play a major role in shaping the development and promotion of sustainable destination. The community is expected to coordinate and assists the participation processes. However, results revealed that representation of limited support from the government or local authority. Further, the finding shows that tourism contributes positively to Guest-Host relationship, regional economy to increase in income and cross-cultural understanding. This confirms that tourism can be an effective tool for promoting peace, which in turn leads to cross-cultural interaction resulting intolerance, national integration, compassion, goodwill, educational standards, justice and mutual respect for each other.

Peace has been seen as a facilitator for tourism development in border areas. It was found out that there is a positive relationship between tourism and peace due to the adequate value of border area regarding tourism development. However, the effects of economic, social and cultural factors are considered as most essential elements which affect the community participation in tourism development programs. Tourism contributes positively to Guest-Host relationship, religious perspective, and cross-cultural understanding. This somewhere shows that tourism can be an effective tool for promoting peace, which in turn leads to destination promotion resulting intolerance, national integration, compassion, goodwill, educational standards, justice and mutual respect for each other. Tourism acts as the lifeline of J\&K and all possible efforts need to be undertaken for retaining, maintaining, and sustaining it. J\&K is the northernmost states of India which is well known for tourism activities. This aspect is responsible for attracting a large number of tourist every year, which has ultimately led to a boom in the tourism industry of the state. J\&K have various mosques and temples Gurudwara stand side by side gives a feeling of pure brotherhood in between religions of J\&K.

The J\&K state is disturbed due to cross-border terrorism, which affected the tourism industry. Therefore, apart from the nature of the problem, other factors like geopolitical, culture, demographics, intro \& inter-regional diversity and so forth can also be considered for the scope of future research. The purpose of this study fulfilled regarding our initiative to use tourism as a tool in bringing people together and uniting the religious beliefs so as to build a harmonious relationship. The tourism Industry is involved with a wide range of stakeholders and the roles of each group are very significant in the realisation of responsible tourism development such as government, tourists, and other small and medium enterprises (SMEs). Therefore, future research should be needed on other stakeholders in the tourism industry.

The major implications of our study are that tourism awareness programs among the host community should be conducted timely so that the locals can get benefits from tourism and can contribute towards the tourism development. Besides this, tour operators should suggest the border-tourism destinations of $\mathrm{J} \& \mathrm{~K}$ region to the tourists and they should include these border tourist attractions in tour packages as well. Further, development of tourism at other border destinations like Suchetgarh, Pragwal to uplift the standard of living of the community. In addition to, different tourism related festivals should be conducted at border tourism destinations of $J \& K$ region in order to increase the tourist flows to these areas. Last but not least, authorities should develop a few museums in the border regions of Jammu region so that to conserve and display the unique history of these areas in them.

In addition, we must state that personal preferences and answers are an important limitation in scientific research. One of the apparent limitations of this study is the sample size, which is slightly small and limited to one region of India. Data was only collected from demand perspective - local residents of $J \& K$. A study with different sample size, several locations, other methodological approach and also by including the stakeholders of the tourism industry in the region may provide fruitful results to check the peace and tranquillity in the particular region. 


\section{References}

Amick, D.J. and Walberg, H.J. (1975). Introductory multivariate analysis. California: McCutchan Publishing Corporation.

Anderson, J., O'Dowd, L. and Wilson, T. (2002). Why study borders now? New borders for a changing Europe: Cross border cooperation and governance. Regional and Federal Studies, 12(4), 1-13.

Anees, S. U. M., Bhat, M. S. and Mishra, O. P. (2015). Field survey on historical monuments for assessment of earthquake resistant structures: Case study of Srinagar capital city of Jammu \& Kashmir, India. International Journal of Scientific and Research Publications, 5(12), 109.

Bhat, B. A. (2014). Exploring the socio-economic coordinates of tourism: A case of Kashmir. Journal of Business \& Economic Policy, 1(1), 9-15.

Budeanu, A. (2005). Impacts and responsibilities for sustainable tourism: a tour operator's perspective. Journal of Cleaner Production, 13(2), 89-97.

Butler, R. W. (2002). The development of tourism in frontier regions: issues and approaches, in Krakover, S. and Grados, Y. (Eds.), Tourism in frontier areas, Lexington Books, Lanham, 25-34.

Chettiparamb, A. and Kokkranikal, J. (2012). Responsible tourism and sustainability: the case of Kumarakom in Kerala, India. Journal of Policy Research in Tourism, Leisure and Events, 4(3), 302-326.

Churchill, A. G. (1979). Marketing research: methodological foundations. Hinsdale, Illinois: Dryden Press.

Cole, M. A. and Neumayer, E. (2004). Examining the impact of demographic factors on air pollution. Population \& Environment, 26(1), 5-21.

D'Amore, L. (1988). Tourism - a vital force for peace. Annals of Tourism Research, 15(2), 269-270.

Dodds, P. S. (2007). Influential, networks, and public opinion formation. Journal of Consumer Research, 34(4), 441-458.

Donaldson, T. and Preston, L. E. (1995). The stakeholder theory of the corporation: Concepts, evidence, and implications. Academy of Management Review, 20(1), 65-91.

Edgell, D. L. (1990). International tourism policy. New York: Van Nostrand Reinhold.

Etiosa, O. (2012). The impacts of event tourism on host communities. Pietarsaari: Central Ostrobothnia University of Applied Sciences.

Farajat, S. A., Liu, B. and Pennington-Gray, L. (2017). Addressing travel writers' role as risk brokers: the case of Jordan. Journal of Policy Research in Tourism, Leisure and Events, 9(1), 23-39.

Field, A. (2000). Discovering Statistics using SPSS for Windows. London, Thousand Oaks, New Delhi: Sage publications.

Gill, A. and Williams, P. (1994). Managing growth in mountain tourism communities. Tourism Management, 15(3), 212-220.

Gunsoy, E. and Hannam, K. (2013). Festivals, community development and sustainable tourism in the Karpaz region of Northern Cyprus. Journal of Policy Research in Tourism, Leisure and Events, 5(1), 81-94.

Hageman, K., Berger, S., Gemie, S. and Williams, C. (2004). Creating and Crossing Borders: The State, Future and Quality of Border Studies. Glamorgan: University of Glamorgan.

Hall, C. M. (2005). Tourism: Rethinking the Social Science of Mobility. London: Pearson Educational.

Haywood, K. M. (1988). Responsible and responsive tourism planning in the community. Tourism Management, 9(2), 105-118. 
Higgins-Desbiolles, F. (2003). Reconciliation tourism: Tourism healing divided societies. Tourism Recreation Research, 28(3), 35-44.

Ioannides, D., Nielsen, P.A. and Billing, P. (2006). Tran boundary collaboration in tourism: The case of the Bothnian Arc. Tourism Geographies, 8(2), 122-142.

Jimenez. C. and Kloeze, T. J. (2014). Analyzing the peace through tourism concept: The challenge for educators. Sociology and Anthropology, 2(3), 63-70.

Kristoff, L.K.D. (1959). The nature of frontiers and boundaries. Annals of Association of American Geographers, 49(3), 269-282.

Kuvan, Y. and Akan, P. (2012). Conflict and agreement in stakeholder attitudes: residents' and hotel managers' views of tourism impacts and forest-related tourism development. Journal of Sustainable Tourism, 20(4), 571-584.

Lai, E. C. C., Man, K. K., Chaiyakunapruk, N., Cheng, C. L., Chien, H. C., Chui, C. S. and Kubota, K. (2015). Brief Report: databases in the Asia-Pacific region: the potential for a distributed network approach. Epidemiology, 26(6), 815-820.

Leong, A. M. W. (2008). International tourism and world peace. Journal of Macau University of Science and Technology, 2(2), 38-44.

Mehrens, W. A. and Lehmann, I. J. (1987). Using standardized tests in education. New York: Longman.

Mihalic, T. (1996). Tourism and Warfare: The case of Slovenia, Tourism, Crime and International Security Issues. New York: John Wiley \& Sons.

Newman, D. (2011). Contemporary research agenda in border studies: an overview', in Waste-Walter, D. (Eds.), The Ashgate Research Companion to Border Studies, Burlington Ashgate, Surrey, 33-47.

Nunnally, J. (1978). Psychometric theory, (2 ${ }^{\text {nd }}$ ed.). New York: McGraw-Hill.

Parasuraman, A., Berry, L. L. and Zeithaml, V.A. (1991). Refinement and reassessment of the SERVQUAL scale. Journal of Retailing, 67(4), 420-450.

Prescott, J.R.V. (1965). The geography of frontiers and boundaries. Chicago, IL: Aldine.

Prokkola, E. K. (2010). Borders in tourism: The transformation of the Swedish-Finnish border landscape. Current Issues in Tourism, 13(3), 223-238.

Raina, A. K. and Agarwal, S. K. (2004). The Essence of tourism development: dynamics, philosophy, and strategies. New Delhi: Sarup \& Sons.

Ranga, M. and Pradhan, P. (2014).Terrorism terrorizes tourism: Indian tourism effacing myths. International Journal of Safety and Security in Tourism/Hospitality, 1(5), 26-39.

Rid, S. A. (2015). Interactive People to People Contacts between India and Pakistan: A case study of Pakistan-India Peoples' Forum for Peace and Democracy (PIPFPD) and Aman ki Asha (Doctoral dissertation, University of Bradford).

Ritchie, J. B. and Crouch, G. I. (2003). The competitive destination: a sustainable tourism perspective. UK: Cabi.

Robinson, P. (2012). Tourism: the key concepts. London and New York: Routledge.

Rukuni, T., Zadzisai, M., Maxwell, C. C. M. and Kwaedza, E. K. (2015). The role of traditional leadership in conflict resolution and peace building in Zimbabwean rural communities: the case of Bikita district. Public Policy and Administration Research, 5(3), 75-79.

Salazar, N. B. (2012). Community-based cultural tourism: issues, threats and opportunities. Journal of Sustainable Tourism, 20(1), 9-22.

Sofield, T. H. B. (2006). Border tourism and border communities: An overview. Tourism Geographies, 8(2), 102-121.

Tarlow, P. E. (2006). A social theory of terrorism and tourism. Tourism, security and safety from theory to practice. Burlington: Elsevier.

Timothy, D. J. (2001). Tourism and political boundaries. London: Routledge. 
Timur, S. (2012). Analyzing urban tourism stakeholder relationships: A network perspective. Haskayne School of Business University of Calgary Working Papers.

United Nations World Tourism Organisation (UNWTO, 2016). Tourism highlights, Madrid, Spain: UNWTO press.

Upadhayaya, P. (2013). Peace through tourism: A critical look at Nepalese tourism. Nepal Tourism and Development Review, 1(1), 15-40.

Van Sterkenburg, J. (2012). Race/ethnicity, sport and the research/policy relationship. The Dutch context. Journal of Policy Research in Tourism, Leisure and Events, 4(1), 112116.

Waligo, V. N. (2012). Human resources and tourism: skills, culture and industry. Tourism Planning \& Development, 9(1), 91-94.

Yu, L. and Chung, M. H. (2001). Tourism as a catalytic force for low-politics activities between politically divided countries: The cases of South/North Korea and Taiwan/China. New Political Science, 23(4), 537-545. 